\title{
Ferulic Acid Suppresses Amyloid $\beta$ Production in the Human Lens Epithelial Cell Stimulated with Hydrogen Peroxide
}

\author{
Noriaki Nagai, ${ }^{1}$ Sachiyo Kotani, ${ }^{1}$ Yu Mano, ${ }^{1}$ Akina Ueno, ${ }^{1}$ Yoshimasa Ito, ${ }^{1}$ \\ Toshio Kitaba, ${ }^{2}$ Takumi Takata, ${ }^{3}$ and Noriko Fujii ${ }^{3}$ \\ ${ }^{1}$ Faculty of Pharmacy, Kindai University, 3-4-1 Kowakae, Higashi-Osaka, Osaka 577-8502, Japan \\ ${ }^{2}$ Kitaba Society, Social Welfare Corporation, 2-2-15 Koyodai, Tondabayashi, Osaka 584-0082, Japan \\ ${ }^{3}$ Research Reactor Institute, Kyoto University, Asashironishi Kumatori, Sennan, Osaka 590-0494, Japan \\ Correspondence should be addressed to Noriko Fujii; nfujii@rri.kyoto-u.ac.jp
}

Received 21 November 2016; Revised 13 February 2017; Accepted 26 February 2017; Published 20 March 2017

Academic Editor: Cheng-Xin Gong

Copyright (C) 2017 Noriaki Nagai et al. This is an open access article distributed under the Creative Commons Attribution License, which permits unrestricted use, distribution, and reproduction in any medium, provided the original work is properly cited.

\begin{abstract}
It is well known that oxidative stresses induce the production of amyloid $\beta(\mathrm{A} \beta)$ in the brain, lens, and retina, leading to agerelated diseases. In the present study, we investigated the effects of ferulic acid on the $\mathrm{A} \beta$ levels in $\mathrm{H}_{2} \mathrm{O}_{2}$-stimulated human lens epithelial (HLE) SRA 01/04 cells. Three types of $\mathrm{A} \beta$ peptides $\left(\mathrm{A} \beta_{1-40}, \mathrm{~A} \beta_{1-42}\right.$, and $\left.\mathrm{A} \beta_{1-43}\right)$ were measured by ELISA, and the levels of mRNA for the expressed proteins related to A $\beta$ production (APP, BACE1, and PS proteins) and degradation (ADAM10, NEP, and ECE1 proteins) were determined by quantitative real-time RT-PCR. $\mathrm{H}_{2} \mathrm{O}_{2}$ stimulation augmented gene expression of the proteins related to $\mathrm{A} \beta$ production, resulting in the production of three types of $\mathrm{A} \beta$ peptides. Treatment with $0.1 \mu \mathrm{M}$ ferulic acid attenuated the augmentations of gene expression and production of the proteins related to the secretion of three types of $A \beta$ peptides in the $\mathrm{H}_{2} \mathrm{O}_{2}$-stimulated HLE cells. These results provided evidence of antioxidative functions of ferulic acid for lens epithelial cells.
\end{abstract}

\section{Introduction}

A sequential proteolytic processing of amyloid precursor protein (APP) cleaved by $\beta$-secretase ( $\beta$ site APP cleaving enzyme, BACE1) [1] and $\gamma$-secretase [a presenilin complex (PS)] [2] leads to the production of amyloid $\beta(A \beta)$ peptides. The cleavage of APP at different positions by $\gamma$-secretase mainly produces three $\mathrm{A} \beta$ peptides, $\mathrm{A} \beta_{1-40}, \mathrm{~A} \beta_{1-42}$, and $\mathrm{A} \beta_{1-43}$ peptides [3-7]. The most abundant variant of $\mathrm{A} \beta$ is $A \beta_{1-40}$, but $A \beta_{1-42}$ and $A \beta_{1-43}$, the longer forms, are more neurotoxic than $\mathrm{A} \beta_{1-40}$. In addition, the neurotoxicity of $A \beta_{1-43}$ is higher than that of $A \beta_{1-42}$, although the accumulation of $\mathrm{A} \beta_{1-43}$ is lower than that of $\mathrm{A} \beta_{1-42}$ [7]. However, the APP cleaved by $\alpha$-secretase (a disintegrin and metalloprotease domain protease 10, ADAM10) generates nonamyloidogenic soluble APP $\alpha$ [8-10]. Neprilysin (NEP) [11] and endothelin converting enzyme (ECE) [12] degrade the $\mathrm{A} \beta$ peptide. The production of $\mathrm{A} \beta$ is a normal process; however, the overproduction of $\mathrm{A} \beta$, or an increased proportion of $\mathrm{A} \beta_{1-42}$ and $\mathrm{A} \beta_{1-43}$, appears to cause an early onset of cataract and Alzheimer's disease [13, 14].
Cataract represents a disease of increasing lens opacity, and it has been reported that $\mathrm{A} \beta$ accumulation in the human lens causes lens opacification [15-18]. In addition, there have been several reports that oxidative stress can increase the accumulation and toxicity of $\mathrm{A} \beta$ peptides in the lens, retina, and brain and that enhanced $\mathrm{A} \beta$ accumulation leads to oxidative stress $[14,19-24]$. Therefore, it is expected that drugs that inhibit the effect of $\mathrm{A} \beta$ peptides and lower oxidative stress can be used as anticataract eye drops.

Ferulic acid (4-hydroxy-3-methoxycinnamic acid) is a widely distributed constituent of plants and is used as an antioxidant to prevent the oxidation of substrates such as lipids, proteins, DNA, and carbohydrates [25, 26]. Ferulic acid has been shown to possess some scavenging activity toward hydroxyl radicals and peroxynitrite $[27,28]$. Recently, several studies have shown that ferulic acid has beneficial effects against Alzheimer's disease [29-31], diabetes [32], and cancer [33]. Alzheimer's disease is a neurodegenerative disorder, and it had been shown that one of the main pathophysiological features of Alzheimer's disease was the presence of extracellular senile plaques consisting essentially of $\mathrm{A} \beta$, a 
peptide thought to be a leading cause of neurotoxicity [34]. It was reported that ferulic acid could be a suitable molecule to specifically bind to $\mathrm{A} \beta$ and inhibit fibril formation [35]. Furthermore, its compact structure could also be used for specific interactions with $\mathrm{A} \beta$ mature fibrils, thereby possibly promoting their destabilization [35]. Ferulic acid inhibits $\mathrm{A} \beta$ aggregation, destabilizes preformed $\mathrm{A} \beta$ fibrils in vitro [36], and protects cultured neuronal cells against $\mathrm{A} \beta$-induced cytotoxicity [29]. Moreover, long-term administration of ferulic acid protects mice against $\mathrm{A} \beta$-induced learning and memory deficits in vivo $[30,31]$. Therefore, ferulic acid may be a useful molecule for the inhibition of $\mathrm{A} \beta$ production and accumulation.

In this study, we investigated the changes in $\mathrm{A} \beta$ production and accumulation in human lens epithelial (HLE) SRA 01/04 cells stimulated with hydrogen peroxide $\left(\mathrm{H}_{2} \mathrm{O}_{2}\right)$. In addition, we demonstrated the preventive effects of ferulic acid on $\mathrm{A} \beta$ production and accumulation in HLE cells.

\section{Materials and Methods}

2.1. Cell Culture and Treatment. The HLE cell line SRA 01/04 was incubated in Dulbecco's Modified Eagle's Medium (DMEM) containing $10 \mu \mathrm{g} / \mathrm{L}$ gentamicin and 10\% (v/v) fetal bovine serum (FBS) under humidified air containing 5\% $\mathrm{CO}_{2}$, at $37^{\circ} \mathrm{C}$. Each treatment was usually carried out on the third day after seeding of $0.4 \times 10^{4}$ cells $/ \mathrm{cm}^{2}$ (at approximately $80 \%$ confluency), and the culture medium was changed to non-FBS medium 1 hour before each experiment. The experiment was initiated by changing the medium to fresh medium containing $0-100 \mu \mathrm{M}$ of $\mathrm{H}_{2} \mathrm{O}_{2}$ and the HLE cells were cultured for 24 hours to produce $\mathrm{A} \beta_{1-40}, \mathrm{~A} \beta_{1-42}$, and $\mathrm{A} \beta_{1-43}\left(\mathrm{H}_{2} \mathrm{O}_{2}\right.$-stimulated HLE cells). Ten $\mu \mathrm{M}$ of $\mathrm{H}_{2} \mathrm{O}_{2}$ and $0-30 \mu \mathrm{M}$ of ferulic acid included in the medium were used for 24-hour cultures to observe the effect of ferulic acid on A $\beta$ production $\left(\mathrm{H}_{2} \mathrm{O}_{2}\right.$-stimulated HLE cells in the presence of ferulic acid).

2.2. Quantitative Real-Time RT-PCR. The experiment was performed as described previously $[14,37]$. Briefly, extraction and purification of the total RNA from HLE cells were performed using an RNase-Free DNase kit and an RNeasy Mini kit (Qiagen, Tokyo, Japan), and an RNA PCR kit (AMV Ver. 3.0, Takara Bio Inc., Shiga, Japan) was used for the reaction according to the manufacturer's instructions. Total RNA $\left(1 \mu \mathrm{g}, \mathrm{OD}_{260} / \mathrm{OD}_{280}\right.$ values $\left.>1.8\right)$ was used for the reverse transcription (RT) reaction, and the reaction was performed at $42^{\circ} \mathrm{C}$ for $15 \mathrm{~min}$, followed by $5 \mathrm{~min}$ at $95^{\circ} \mathrm{C}$. The PCR reactions were performed using LightCycler ${ }^{\circledR}$ FastStart DNA Master SYBR Green I according to the manufacturer's instructions (Roche Diagnostics Applied Science, Mannheim, Germany), and the quantities of the PCR products were measured fluorometrically in a realtime manner using a LightCycler ${ }^{\circledR}$ DX 400 (Roche Diagnostics Applied Science). In this study, the specific primers (10 pmol) for APP, BACE1, PS1, PS2, ADAM10, NEP, ECE1, or glyceraldehyde-3-phosphate dehydrogenase (GAPDH) were as follows: $5^{\prime}$-TGGTGGGCGGTGTTGTCATA-3' (forward; FOR) and $5^{\prime}$-TGGATTTTCGTAGCCGTTCTGC$3^{\prime}$ (reverse; REV) for APP; 5'-GCAAGGAGTACAACTATGAC-3' (FOR) and $5^{\prime}$-AGCTTCAAACACTTTCTTGG-3' (REV) for BACE1; 5' -ATCATCTGCATAGTCCTCTC-3' (FOR) and $5^{\prime}$-AGACAGCTTTGATGTTCAAG-3' (REV) for PS1; $5^{\prime}$-TACAAGTACCGCTGCTACAAGTTC$3^{\prime}$ (FOR) and $5^{\prime}$-GCACTTCCCCAAGGTAGATATAGG$3^{\prime}$ (REV) for PS2; 5'-CACATGATTCTGGAACAGAG-3' (FOR) and $5^{\prime}$-GTTGTTAAGTTTGTCCCCAG-3' (REV) for ADAM10; $5^{\prime}$-CTGATATCAACACTCCAAAGC-3' (FOR) and $5^{\prime}$-TCATCGTAGGTTGCATAGAG-3' (REV) for NEP; $5^{\prime}$-AGAATGAGATTGTGTTTCCG-3' (FOR) and $5^{\prime}$-CTATGCCACCAAAGTTTAAGG-3' (REV) for ECE1; and $5^{\prime}$ TGCACCACCAACTGCTTAGC-3' (FOR) and $5^{\prime}$-GGCATGGACTGTGGTCATGAG-3' (REV) for GAPDH. The conditions for PCR were $95^{\circ} \mathrm{C}$ for $10 \mathrm{~min}$ (hot start), 60 cycles of $95^{\circ} \mathrm{C}$ for $10 \mathrm{~s}$ (denaturing), $63^{\circ} \mathrm{C}$ for $10 \mathrm{~s}$ (annealing), and $72^{\circ} \mathrm{C}$ for $5 \mathrm{~s}$ (extension). The differences in the threshold cycles for target groups (APP, BACE1, PS1, PS2 ADAM10, NEP, and ECE1) and GAPDH were used to calculate the levels of mRNA expression in HLE cells.

2.3. Measurement of $A \beta$. The measurements of $\mathrm{A} \beta_{1-40}$, $\mathrm{A} \beta_{1-42}$, and $\mathrm{A} \beta_{1-43}$ levels were performed as previously described [14, 38]. Approximately $2.5 \times 10^{6}$ HLE cells were collected with a cell scraper (Asahi Glass, Tokyo, Japan), homogenized in $250 \mu \mathrm{L}$ of $70 \%$ formic acid, and then centrifuged at $9,100 \times \mathrm{g}$ for $15 \mathrm{~min}$ at $4^{\circ} \mathrm{C}$. The supernatants were added to $4.75 \mathrm{~mL}$ of $1 \mathrm{M}$ Tris base, and the mixtures were used for the measurements of the $\mathrm{A} \beta_{1-40}, \mathrm{~A} \beta_{1-42}$, and $\mathrm{A} \beta_{1-43}$ peptides. The $\mathrm{A} \beta_{1-40}, \mathrm{~A} \beta_{1-42}$, and $\mathrm{A} \beta_{1-43}$ levels were measured using the human $\beta$ amyloid (40) ELISA kit (dynamic range, 1-100 pM, Wako, Osaka, Japan), the human $\beta$ amyloid (42) ELISA kit (dynamic range, 0.1-20 pM, Wako), and the human amyloid $\beta$ (1-43) (FL) ELISA kit (dynamic range, 0.51-32.5 pM, IBL, Gunma, Japan) according to the manufacturer's instructions, respectively. The $\mathrm{A} \beta$ levels were expressed as $\mathrm{pmol} / \mathrm{g}$ of protein according to our previous reports. The protein levels in the samples used to determine $\mathrm{A} \beta_{1-40}, \mathrm{~A} \beta_{1-42}$, and $\mathrm{A} \beta_{1-43}$ were assessed using a Bio-Rad Protein Assay kit (Bio-Rad, Hercules, CA, USA).

2.4. Measurement of Cell Viability. HLE cells with or without added $\mathrm{H}_{2} \mathrm{O}_{2}$ and ferulic acid treatments were incubated in 96-well microplates (Iwaki, Chiba, Japan). The viability of the HLE cells was calculated by the Cell Count Reagent SF kit (Nacalai Tesque, Kyoto, Japan) according to the manufacturer's instructions. The absorbance at $450 \mathrm{~nm}$ was measured, and the cell viability (\%) was represented as the percentage of the absorbance measured for unstimulated HLE cells for each point (normal cells).

2.5. Statistical Analyses. All values were presented as mean \pm standard error (SE), and statistical differences were evaluated by one-way analysis of variance followed by Dunnett's multiple comparisons. $P$ values of less than 0.05 were considered significant. 


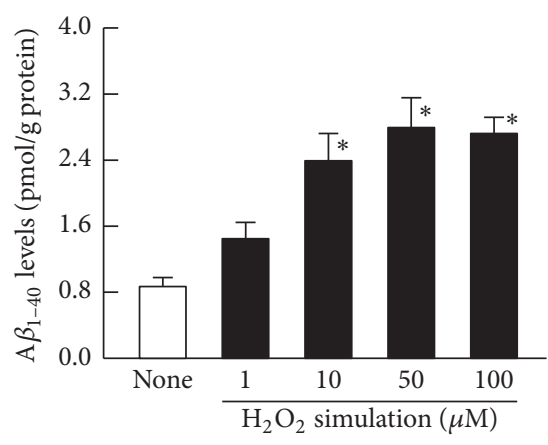

(a) $\mathrm{A} \beta_{1-40}$ levels

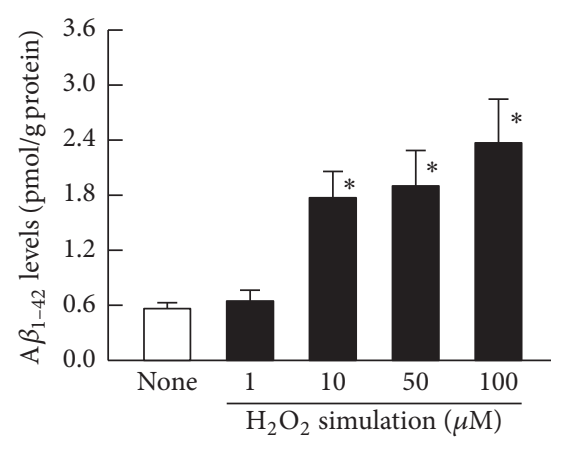

(b) $\mathrm{A} \beta_{1-42}$ levels

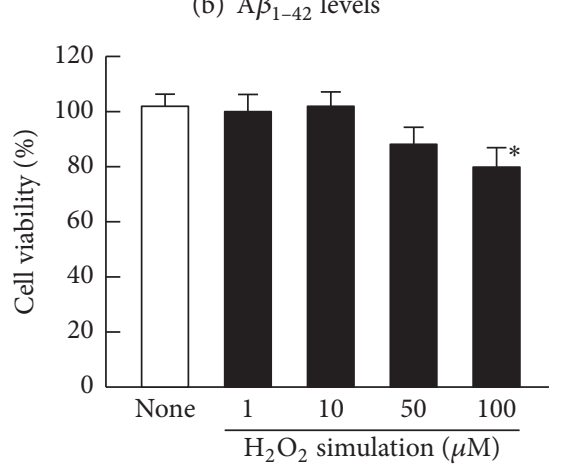

(d) Cell viability

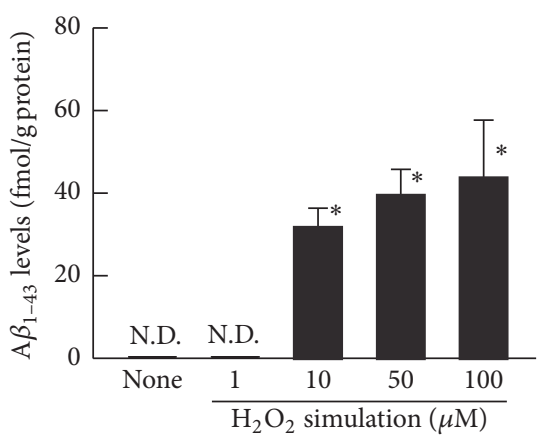

(c) $\mathrm{A} \beta_{1-43}$ levels

FIGURE 1: Effect of $\mathrm{H}_{2} \mathrm{O}_{2}$ stimulation on $\mathrm{A} \beta_{1-40}$ (a), $\mathrm{A} \beta_{1-42}$ (b), $\mathrm{A} \beta_{1-43}$ (c), and cell viability (d) in HLE cells. The HLE cells were stimulated by 1-100 $\mu \mathrm{M} \mathrm{H}_{2} \mathrm{O}_{2}$ for $24 \mathrm{~h}$. Open columns (none) = unstimulated HLE cells. Closed columns $=\mathrm{H}_{2} \mathrm{O}_{2}$-stimulated HLE cells. N.D. = not detectable. The data are presented as the means \pm SE of $5-8$ experiments. ${ }^{*} P<0.05$, versus none for each category.

\section{Results}

3.1. The Effect of $\mathrm{H}_{2} \mathrm{O}_{2}$ Stimulation on $\mathrm{A} \beta$ Production and Accumulation in HLE Cells. Figures $1(\mathrm{a})-1(\mathrm{c})$ shows the levels of $\mathrm{A} \beta$ accumulation in the $\mathrm{H}_{2} \mathrm{O}_{2}$-stimulated HLE cells. The $\mathrm{A} \beta_{1-40}$ and $\mathrm{A} \beta_{1-42}$ levels were enhanced with increasing $\mathrm{H}_{2} \mathrm{O}_{2}$ concentration. Although the $\mathrm{A} \beta_{1-43}$ was not detected in the unstimulated HLE cells, an accumulation of $\mathrm{A} \beta_{1-43}$ was observed with stimulation by $10-100 \mu \mathrm{M} \mathrm{H}_{2} \mathrm{O}_{2}$. Figure $1(\mathrm{~d})$ shows the cell viability in the $\mathrm{H}_{2} \mathrm{O}_{2}$-stimulated HLE cells. The cell viability in the $1 \mu \mathrm{M}$ and $10 \mu \mathrm{M} \mathrm{H}_{2} \mathrm{O}_{2}$-stimulated HLE cells was similar to that of the unstimulated HLE cells (None). However, the HLE cell viabilities in the presence of $50 \mu \mathrm{M}$ and $100 \mu \mathrm{M} \mathrm{H}_{2} \mathrm{O}_{2}$ were decreased, and the cell viability at $100 \mu \mathrm{M} \mathrm{H}_{2} \mathrm{O}_{2}$ was significantly lower than that of the untreated cells (None). Figure 2 shows the mRNA levels for proteins related to $\mathrm{A} \beta$ production (APP, BACE1, PS1, and PS2) and to degradation (ADAM10, NEP, and ECE1) in the $\mathrm{H}_{2} \mathrm{O}_{2}$-stimulated HLE cells. APP, BACE1, and PS1 mRNAs were increased with increasing concentrations of $\mathrm{H}_{2} \mathrm{O}_{2}$, while PS2 mRNA levels were not altered. The $\mathrm{H}_{2} \mathrm{O}_{2}$ stimulation did not change the mRNA levels of proteins related to $\mathrm{A} \beta$ degradation (ADAM10, NEP, and ECE1).

3.2. The Preventive Effects of Ferulic Acid on Enhanced A $\beta$ Production and Accumulation in $\mathrm{H}_{2} \mathrm{O}_{2}$-Stimulated HLE Cells.
Figures 3(a)-3(c) show the effects of ferulic acid on the specific $\mathrm{A} \beta$ levels in the $10 \mu \mathrm{M} \mathrm{H}_{2} \mathrm{O}_{2}$-stimulated HLE cells. At $0.01-0.1 \mu \mathrm{M}$ of ferulic acid, $\mathrm{A} \beta$ levels were relatively decreased in the $\mathrm{H}_{2} \mathrm{O}_{2}$-stimulated HLE cells. However, at $30 \mu \mathrm{M}$ of ferulic acid, the $\mathrm{A} \beta$ levels were higher than those at $0.1 \mu \mathrm{M}$ of ferulic acid; thus, the preventive effects of the $\mathrm{A} \beta$ level increase peaked at $0.1 \mu \mathrm{M}$ of ferulic acid. Figure $3(\mathrm{~d})$ shows the effect of ferulic acid on cell viability in the $\mathrm{H}_{2} \mathrm{O}_{2}$ stimulated HLE cells. A decrease in cell viability was not observed at $0.01-30 \mu \mathrm{M}$ of ferulic acid. Figure 4 shows the effects of ferulic acid on the mRNA levels for proteins related to $\mathrm{A} \beta$ production (APP, BACE1, PS1, and PS2) and degradation (ADAM10, NEP, and ECE1) in the $\mathrm{H}_{2} \mathrm{O}_{2}$-stimulated HLE cells. Ferulic acid decreased the mRNA levels of APP, BACE1, and PS1. However, the mRNA levels of PS2 and the mRNA levels for proteins related to A $\beta$ degradation (ADAM10, NEP, and ECE1) in HLE cells treated with ferulic acid were similar to the HLE cells without ferulic acid treatment.

3.3. The Effects of Ferulic Acid on A $\beta$ Production and Accumulation in HLE Cells. Because $0.1 \mu \mathrm{M}$ of ferulic acid showed the greatest suppression of the production of $\mathrm{A} \beta$, we further determined the impact of $0.1 \mu \mathrm{M}$ of ferulic acid on the HLE cells without $\mathrm{H}_{2} \mathrm{O}_{2}$ stimulation (Figure 5). As shown in Figure 5, the $\mathrm{A} \beta_{1-43}$ level was not detected by the HLE cells treated with or without $0.1 \mu \mathrm{M}$ ferulic acid, and $\mathrm{A} \beta_{1-40}$ levels 


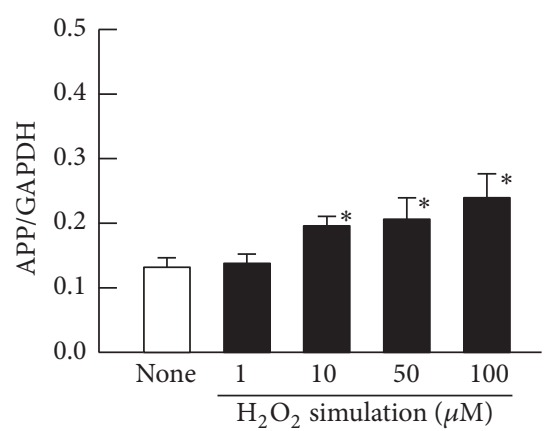

(a) APP mRNA

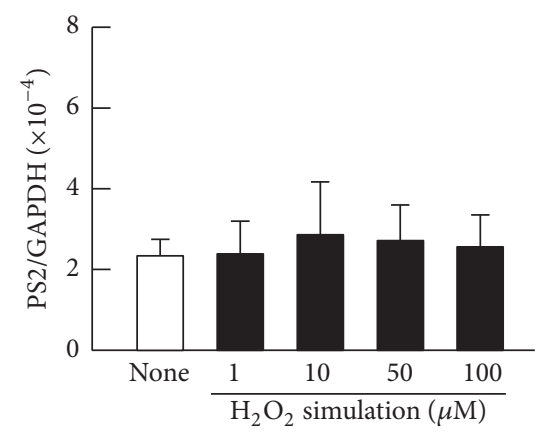

(d) PS2 mRNA

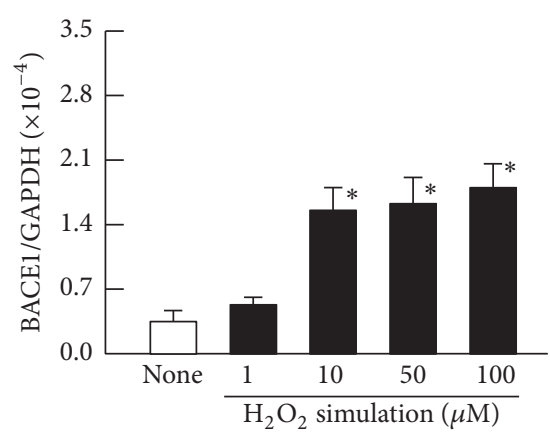

(b) BACE1 mRNA

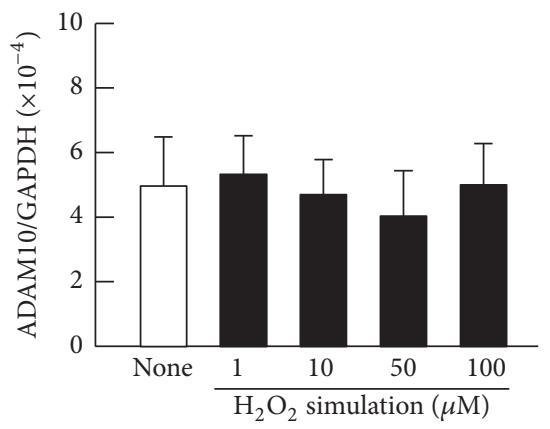

(e) ADAM10 mRNA

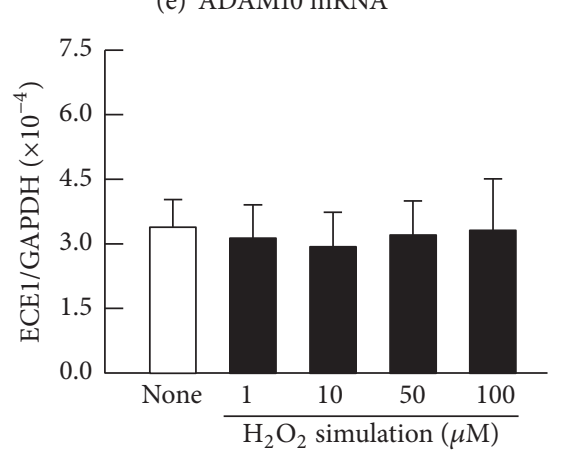

(g) ECE1 mRNA

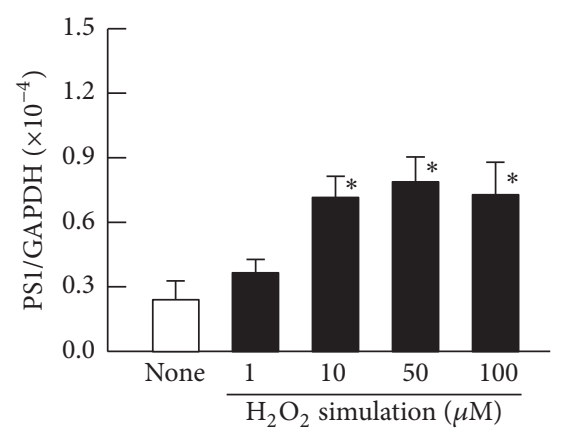

(c) PS1 mRNA

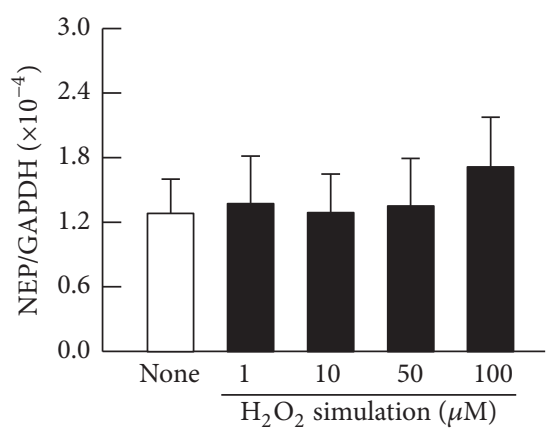

(f) NEP mRNA

Figure 2: Effect of $\mathrm{H}_{2} \mathrm{O}_{2}$ stimulation on mRNA levels of APP (a), BACE1 (b), PS1 (c), PS2 (d), ADAM10 (e), NEP (f), and ECE1 (g) in HLE cells. The HLE cells were stimulated with 1-100 $\mu \mathrm{M} \mathrm{H}_{2} \mathrm{O}_{2}$ for $24 \mathrm{~h}$. Open columns (none) = unstimulated HLE cells. Closed columns = $\mathrm{H}_{2} \mathrm{O}_{2}$-stimulated HLE cells. The data are presented as the means \pm SE of 5-8 experiments. ${ }^{*} \mathrm{P}<0.05$, versus none for each category.

and the mRNA levels of proteins related to $A \beta$ production (APP, BACE1, PS1, and PS2) and degradation (ADAM10, NEP, and ECE1) were similar to those of the naïve HLE cells. On the other hand, the $\mathrm{A} \beta_{1-42}$ levels in HLE cells, treated with $0.1 \mu \mathrm{M}$ ferulic acid, were significantly lower than that without ferulic acid.

\section{Discussion}

In the cataractous lens, an accumulation of $\mathrm{A} \beta$ peptide was observed, and lens opacification occurred via oxidative stress $[14,15]$. Therefore, the prevention of $\mathrm{A} \beta$ accumulation in the lens is important for cataract therapy. In this study, we investigated whether treatments with ferulic acid prevented the $\mathrm{A} \beta$ production and accumulation in the human lens and showed that ferulic acid attenuated the increase in the mRNA levels of proteins related to $A \beta$ production (APP, BACE1, and PS1) and prevented the accumulation of $\mathrm{A} \beta_{1-40}, \mathrm{~A} \beta_{1-42}$, and $\mathrm{A} \beta_{1-43}$ in $\mathrm{H}_{2} \mathrm{O}_{2}$-stimulated HLE cells.

Previous reports showed that the $\mathrm{A} \beta$ levels in the retina and brain were enhanced by oxidative stress [19-24]. In addition, we also reported that $\mathrm{H}_{2} \mathrm{O}_{2}$ in the rat lens induced lipid peroxidation and led to the accumulation of $\mathrm{A} \beta_{1-42}$ in the lens epithelium [14]. Therefore, in our current study, the HLE cells were exposed to $\mathrm{H}_{2} \mathrm{O}_{2}$ to enhance the $\mathrm{A} \beta$ production. The results clearly suggested that $10 \mu \mathrm{M}$ of $\mathrm{H}_{2} \mathrm{O}_{2}$ induced $\mathrm{A} \beta$ production, whereas $0.01-0.1 \mu \mathrm{M}$ of ferulic acid significantly decreased the mRNAs (APP, BACE1, and PS1) related to $\mathrm{A} \beta$ production (Figure 4 ) and the $\mathrm{A} \beta$ production in $\mathrm{H}_{2} \mathrm{O}_{2}$-stimulated HLE cells (Figure 3 ). It was previously 


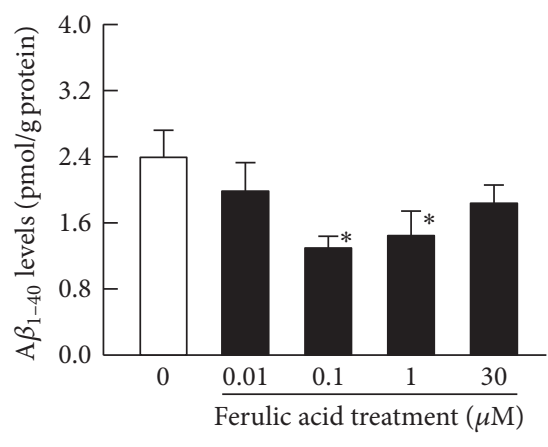

(a) $\mathrm{A} \beta_{1-40}$ levels

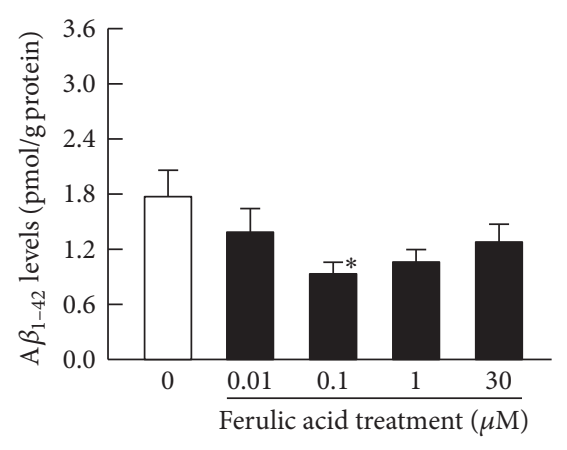

(b) $\mathrm{A} \beta_{1-42}$ levels

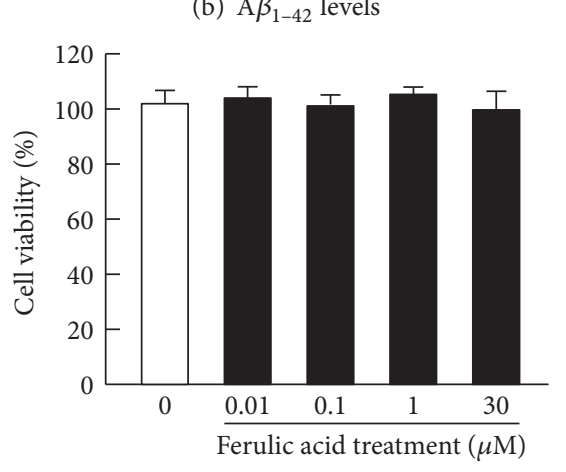

(d) Cell viability

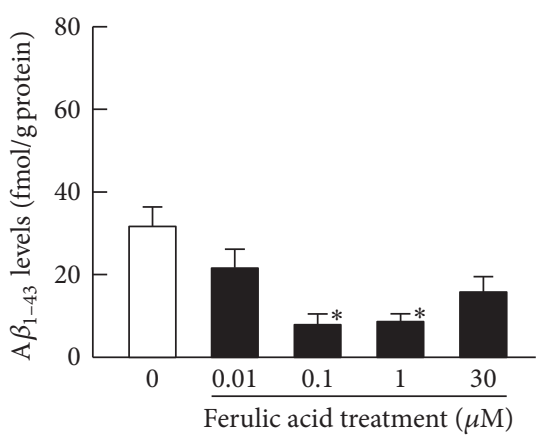

(c) $\mathrm{A} \beta_{1-43}$ levels FIGURE 3: The effect of ferulic acid on $\mathrm{A} \beta_{1-40}$ (a), A $\beta_{1-42}$ (b), A $\beta_{1-43}$ (c), and cell viability (d) in $10 \mu \mathrm{M} \mathrm{H}_{2} \mathrm{O}_{2}$-stimulated HLE cells. The $10 \mu \mathrm{M}$
$\mathrm{H}_{2} \mathrm{O}_{2}$ and $0-30 \mu \mathrm{M}$ ferulic acid were added simultaneously to the medium, and the HLE cells were incubated for 24 h. Open columns $=$ $\mathrm{H}_{2} \mathrm{O}_{2}$-stimulated HLE cells. Closed columns $=\mathrm{H}_{2} \mathrm{O}_{2}$-stimulated HLE cells with ferulic acid treatment. The data are presented as the means $\pm \mathrm{SE}$ of 5-8 experiments. ${ }^{*} \mathrm{P}<0.05$, versus $\mathrm{H}_{2} \mathrm{O}_{2}$-stimulated HLE cells in the absence of ferulic acid (open columns) for each category.

reported that oxidative stress increased the accumulation of $\mathrm{A} \beta$ in the lens, retina, and brain $[14,19-24]$. In addition, ferulic acid has been shown to possess some scavenging activity for hydroxyl radicals and peroxynitrite $[27,28]$ and to inhibit the oxidation of substrates. Taken together, our results suggested that $0.1 \mu \mathrm{M}$ and $1 \mu \mathrm{M}$ of ferulic acid may prevent $\mathrm{H}_{2} \mathrm{O}_{2}$ effects, resulting in a decrease of specific mRNAs and in $\mathrm{A} \beta$ accumulation. However, the mRNA levels of proteins related to $\mathrm{A} \beta$ production (APP, BACE1, and PS) in HLE cells incubated with $30 \mu \mathrm{M}$ of ferulic acid were similar to that of the $\mathrm{H}_{2} \mathrm{O}_{2}$-stimulated HLE cells incubated with $0.1 \mu \mathrm{M}$ of ferulic acid (Figure 4). However, the $\mathrm{A} \beta_{1-40}, \mathrm{~A} \beta_{1-42}$, and $\mathrm{A} \beta_{1-43}$ levels in the HLE cells stimulated with $30 \mu \mathrm{M}$ of ferulic acid were elevated when compared with those of the $\mathrm{H}_{2} \mathrm{O}_{2}$ stimulated HLE cells incubated with $0.1 \mu \mathrm{M}$ of ferulic acid (Figure 3). It was reported that ferulic acid undergoes specific interactions with $\mathrm{A} \beta$ mature fibrils, possibly promoting their destabilization [35]. Moreover, ferulic acid inhibited A $\beta$ aggregation and destabilized preformed $\mathrm{A} \beta$ fibrils [36]. From these findings, the destabilization of $\mathrm{A} \beta$ fibrils by ferulic acid may be related to the difference in the levels of $\mathrm{A} \beta$ in the HLE cells treated with $0.1 \mu \mathrm{M}$ and $30 \mu \mathrm{M}$ of ferulic acid. In this study, the $\mathrm{A} \beta$ monomer in/on the cells would be measured, since the HLE cells were collected, and all protein fractions were precipitated with $70 \%$ formic acid. We tried to measure the $\mathrm{A} \beta$ levels in medium; however the $\mathrm{A} \beta$ levels were not detected by using ELISA method. We hypothesize that both the fibrils and monomeric $\mathrm{A} \beta$ are present in the medium but were below the detection level of the ELISA assay. For the certification of this hypothesis, there is a need to measure the levels of $\mathrm{A} \beta$ in the medium by using high resolution mass spectrometry in future studies.

On the other hand, $0.1 \mu \mathrm{M}$ of ferulic acid shows different effects between $\mathrm{A} \beta_{1-40}$ and $\mathrm{A} \beta_{1-42}$ levels (Figure 5). It was known that the $\mathrm{A} \beta_{1-42}$ was easy to aggregate in comparison with $\mathrm{A} \beta_{1-40}$; however, the amount of $\mathrm{A} \beta_{1-42}$ production was lower than that of $\mathrm{A} \beta_{1-40}$ [7]. Therefore, the destabilization of $A \beta$ aggregation by ferulic acid may strongly affect the $\mathrm{A} \beta_{1-42}$ in comparison with $\mathrm{A} \beta_{1-40}$. Further studies are needed to elucidate the precise mechanisms for the prevention of $\mathrm{A} \beta$ production and the accumulation by ferulic acid in the lens. In addition, it is important to measure the ratio of $A \beta$ fibrils and $\mathrm{A} \beta$ monomers to clarify the molecular mechanism involved in the downregulation of APP, BACE1, and PS1 mRNAs in ferulic acid treated cells. Therefore, we are now investigating the protein expression and aggregation of $\mathrm{A} \beta$ in $\mathrm{H}_{2} \mathrm{O}_{2}$-stimulated HLE cells incubated with $0.1 \mu \mathrm{M}$ and $30 \mu \mathrm{M}$ of ferulic acid by using western blotting and immunostaining methods. Moreover, we are developing a drug delivery system for ferulic acid to the lens. In the future, we will determine the in vivo effects of a ferulic acid ophthalmic formulation on lens opacification and $\mathrm{A} \beta$ accumulation in the UPL rat model. 


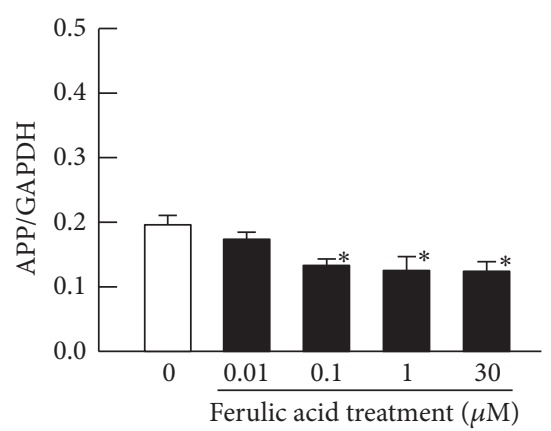

(a) APP mRNA

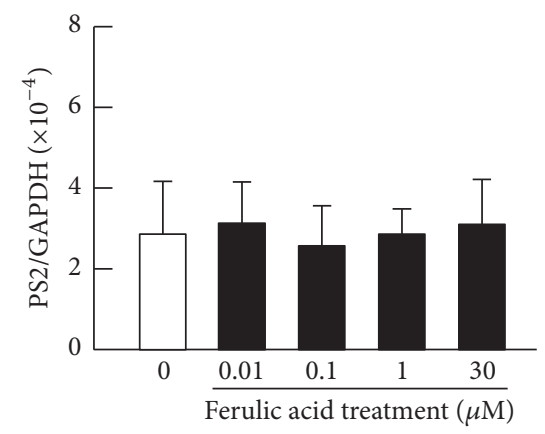

(d) PS2 mRNA

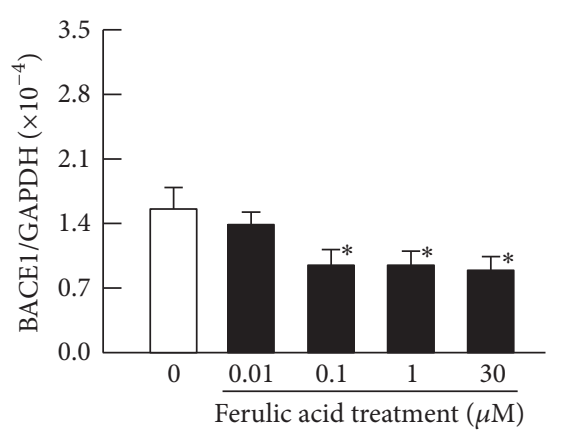

(b) BACE1 mRNA

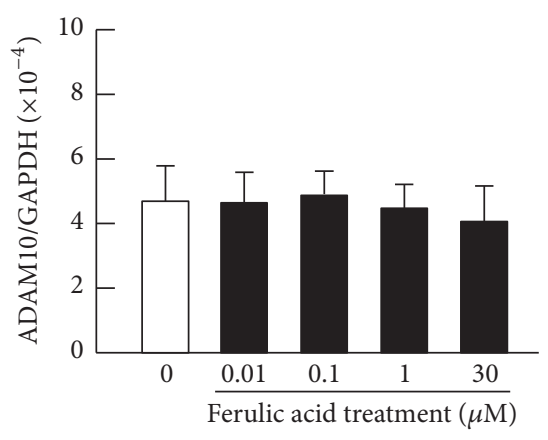

(e) ADAM10 mRNA

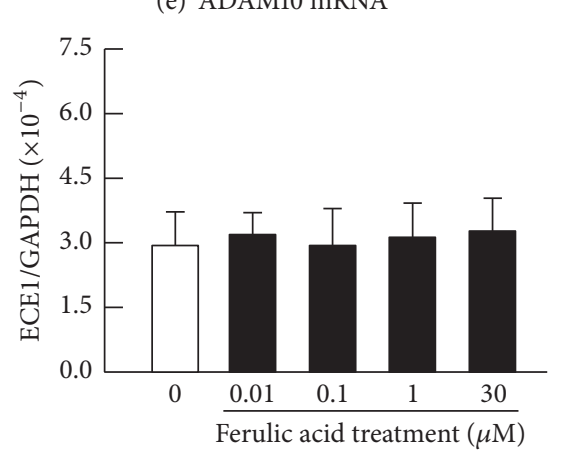

(g) ECE1 mRNA

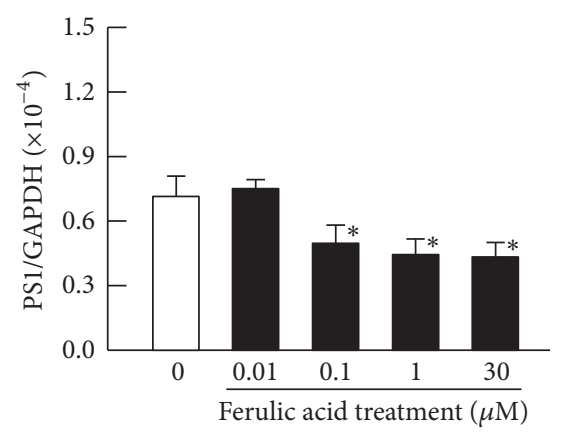

(c) PS1 mRNA

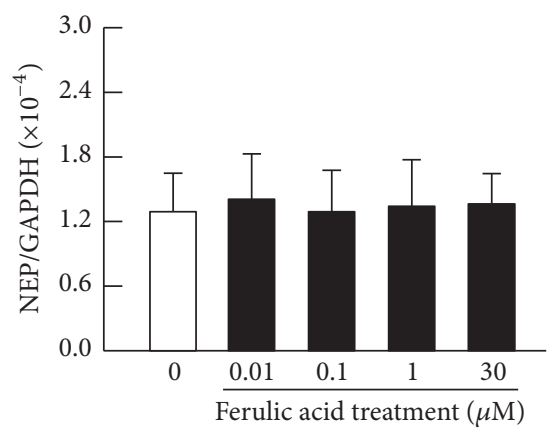

(f) NEP mRNA

Figure 4: The effect of ferulic acid on mRNA levels of APP (a), BACE1 (b), PS1 (c), PS2 (d), ADAM10 (e), NEP (f), and ECE1 (g) in $\mathrm{H}_{2} \mathrm{O}_{2}$ stimulated HLE cells. The $10 \mu \mathrm{M} \mathrm{H}_{2} \mathrm{O}_{2}$ and $0-30 \mu \mathrm{M}$ ferulic acid were added simultaneously to the medium, and the HLE cells were incubated for $24 \mathrm{~h}$. Open columns $=\mathrm{H}_{2} \mathrm{O}_{2}$-stimulated HLE cells. Closed columns $=\mathrm{H}_{2} \mathrm{O}_{2}$-stimulated HLE cells with ferulic acid treatment. The data are presented as the means \pm SE of 5-8 experiments. ${ }^{*} \mathrm{P}<0.05$, versus $\mathrm{H}_{2} \mathrm{O}_{2}$-stimulated HLE cells in the absence of ferulic acid (open columns) for each category.

\section{Conclusions}

We have shown that stimulation with $\mathrm{H}_{2} \mathrm{O}_{2}$ leads to increased mRNA levels of proteins related to $\mathrm{A} \beta$ production (APP, BACE1, and PS) and to an enhanced accumulation of $\mathrm{A} \beta_{1-40}$, $\mathrm{A} \beta_{1-42}$, and $\mathrm{A} \beta_{1-43}$ in HLE cells. In addition, we showed that treatments with ferulic acid attenuated the increases in the mRNA levels of proteins related to $\mathrm{A} \beta$ production and prevented $\mathrm{A} \beta_{1-40}, \mathrm{~A} \beta_{1-42}$, and $\mathrm{A} \beta_{1-43}$ accumulation in $\mathrm{H}_{2} \mathrm{O}_{2}$ stimulated HLE cells. An ophthalmic eye drop formulation containing ferulic acid could prevent both oxidative stress and $\mathrm{A} \beta$ accumulation in HLE cells, resulting in the suppression of lens opacification during cataract. This study provides significant information that can therefore be used to design further studies aimed at developing anticataract drugs.

\section{Conflicts of Interest}

The authors declare no conflicts of interest. The authors alone are responsible for the content and writing of the paper.

\section{Acknowledgments}

This work was supported in part by Grant 25288075, from the Ministry of Education, Culture, Sports, Science, and Technology of Japan. 


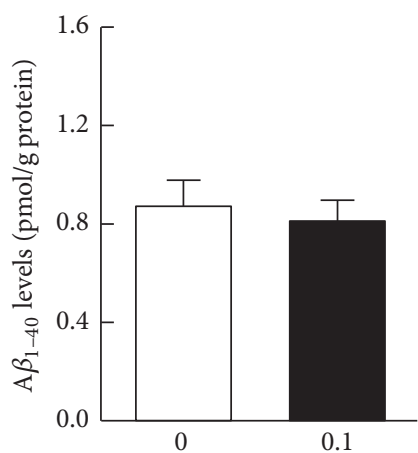

Ferulic acid treatment $(\mu \mathrm{M})$

(a) $\mathrm{A} \beta_{1-40}$ levels

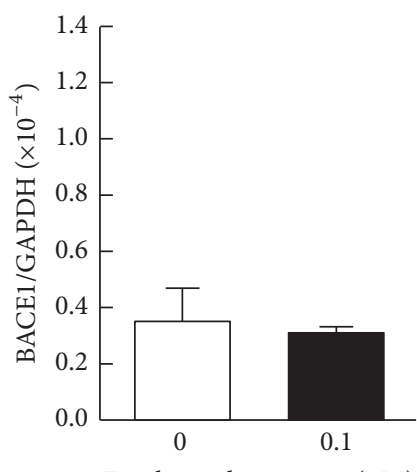

Ferulic acid treatment $(\mu \mathrm{M})$

(e) BACE1 mRNA

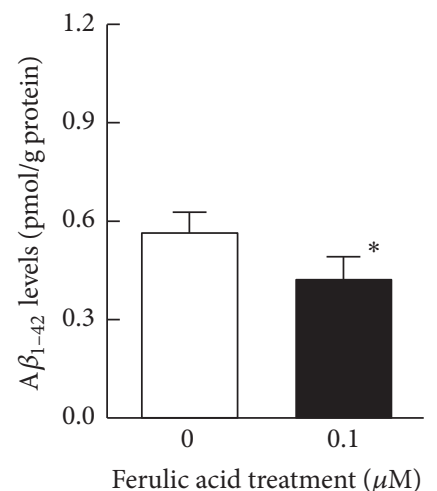

(b) $\mathrm{A} \beta_{1-42}$ levels

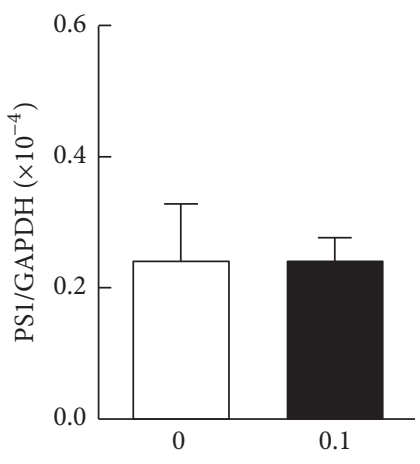

Ferulic acid treatment $(\mu \mathrm{M})$

(f) PS1 mRNA

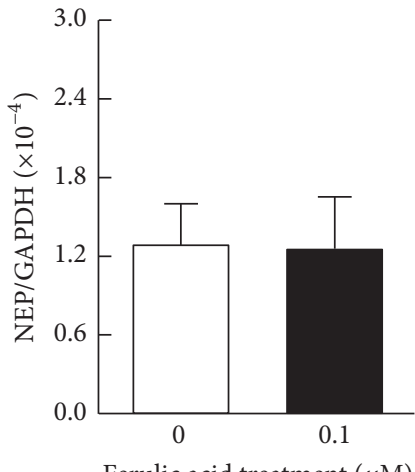

(i) NEP mRNA

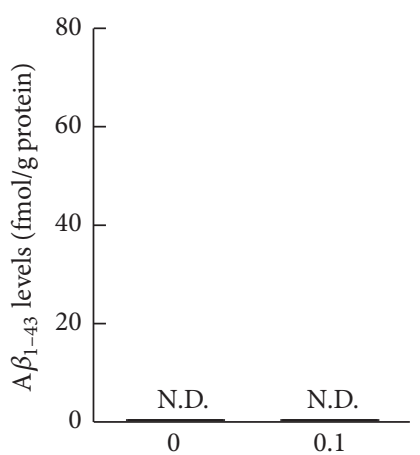

Ferulic acid treatment $(\mu \mathrm{M})$

(c) $\mathrm{A} \beta_{1-43}$ levels

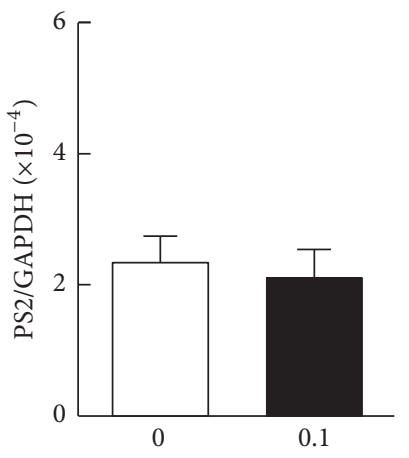

Ferulic acid treatment $(\mu \mathrm{M})$

(g) PS2 mRNA

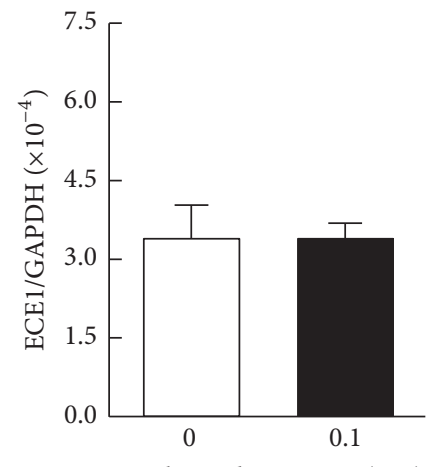

Ferulic acid treatment $(\mu \mathrm{M})$

(j) ECE1 mRNA

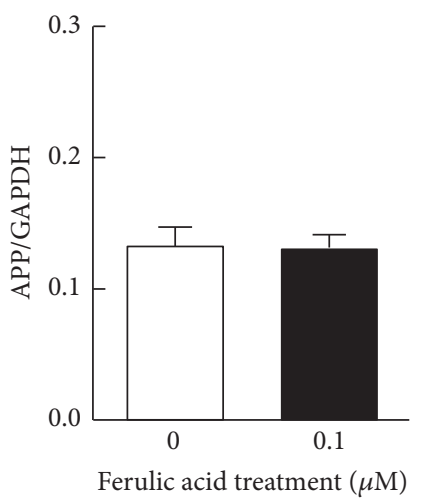

(d) APP mRNA

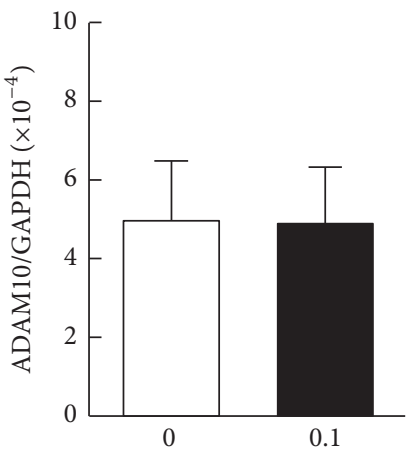

Ferulic acid treatment $(\mu \mathrm{M})$

(h) ADAM10 mRNA

Figure 5: The effect of $0.1 \mu \mathrm{M}$ of ferulic acid on the production of $\mathrm{A} \beta_{1-40}$ (a), $\mathrm{A} \beta_{1-42}$ (b), $\mathrm{A} \beta_{1-43}$ (c) levels, and mRNA levels of APP (d), BACE1 (e), PS1 (f), PS2 (g), ADAM10 (h), NEP (i), and ECE1 (j) in HLE cells. The $0.1 \mu \mathrm{M}$ of ferulic acid was added simultaneously to the medium, and the HLE cells were incubated for $24 \mathrm{~h}$. Open columns = the naive HLE cells. Closed columns $=$ HLE cells in the presence of $0.1 \mu \mathrm{M}$ ferulic acid. N.D. $=$ not detectable. The data are presented as the means \pm SE of five experiments. ${ }^{*} P<0.05$, versus naïve HLE cells (open columns) for each category.

\section{References}

[1] R. Vassar, B. D. Bennett, S. Babu-Khan et al., " $\beta$-Secretase cleavage of Alzheimer's amyloid precursor protein by the transmembrane aspartic protease BACE," Science, vol. 286, no. 5440, pp. 735-741, 1999.

[2] N. Takasugi, T. Tomita, I. Hayashi et al., "The role of presenilin cofactors in the $\gamma$-secratase complex," Nature, vol. 422, no. 6930, pp. 438-441, 2003.
[3] P.-E. Fraser, J.-T. Nguyen, H. Inouye et al., "Fibril formation by primate, rodent, and dutch-hemorrhagic analogues of Alzheimer amyloid $\beta$-protein," Biochemistry, vol. 31, no. 44, pp. 10716-10723, 1992.

[4] A. I. Bush, W. H. Pettingell, G. Multhaup et al., "Rapid induction of Alzheimer A $\beta$ amyloid formation by zinc," Science, vol. 265, no. 5177, pp. 1464-1467, 1994.

[5] A. Lorenzo and B. A. Yankner, " $\beta$-amyloid neurotoxicity requires fibril formation and is inhibited by Congo red," 
Proceedings of the National Academy of Sciences of the United States of America, vol. 91, no. 25, pp. 12243-12247, 1994.

[6] J. Ma, A. Yee, H. B. Brewer Jr., S. Das, and H. Potter, "Amyloidassociated proteins $\alpha_{1}$-antichymotrypsin and apolipoprotein E promote assembly of Alzheimer $\beta$-protein into filaments," Nature, vol. 372, no. 6501, pp. 92-94, 1994.

[7] T. Saito, T. Suemoto, N. Brouwers et al., "Potent amyloidogenicity and pathogenicity of A $\beta 243$," Nature Neuroscience, vol. 14, no. 8, pp. 1023-1032, 2011.

[8] H. Zheng and E. H. Koo, "The amyloid precursor protein: beyond amyloid," Molecular Neurodegeneration, vol. 1, no. 1, article 5, 2006.

[9] T.-L. Kukar, T.-B. Ladd, M.-A. Bann et al., "Substrate-targeting $\gamma$-secretase modulators," Nature, vol. 453, no. 7197, pp. 925-929, 2008.

[10] P. C. Wong, "Translational control of BACE1 may go awry in Alzheimer's disease," Neuron, vol. 60, no. 6, pp. 941-943, 2008.

[11] N. Iwata, Y. Takaki, S. Fukami, S. Tsubuki, and T. C. Saido, "Region-specific reduction of $\mathrm{A} \beta$-degrading endopeptidase, neprilysin, in mouse hippocampus upon aging," Journal of Neuroscience Research, vol. 70, no. 3, pp. 493-500, 2002.

[12] E. A. Eckman, D. K. Reed, and C. B. Eckman, "Degradation of the Alzheimer's amyloid $\beta$ peptide by endothelin-converting enzyme," The Journal of Biological Chemistry, vol. 276, no. 27, pp. 24540-24548, 2001.

[13] J. Hardy and D.-J. Selkoe, "The amyloid hypothesis of Alzheimer's disease: progress and problems on the road to therapeutics," Science, vol. 297, no. 5580, pp. 353-356, 2002.

[14] N. Nagai and Y. Ito, "Excessive hydrogen peroxide enhances the attachment of amyloid $\beta 1-42$ in the lens epithelium of UPL rats, a hereditary model for cataracts," Toxicology, vol. 315, no. 1, pp. 55-64, 2014.

[15] L. E. Goldstein, J. A. Muffat, R. A. Cherny et al., "Cytosolic $\beta$ amyloid deposition and supranuclear cataracts in lenses from people with Alzheimer's disease," Lancet, vol. 361, no. 9365, pp. 1258-1265, 2003.

[16] S. Meehan, Y. Berry, B. Luisi, C. M. Dobson, J. A. Carver, and C. E. MacPhee, "Amyloid fibril formation by lens crystallin proteins and its implications for cataract formation," Journal of Biological Chemistry, vol. 279, no. 5, pp. 3413-3419, 2004.

[17] J. A. Moncaster, R. Pineda, R. D. Moir et al., "Alzheimer's disease amyloid- $\beta$ links lens and brain pathology in down syndrome," PLOS ONE, vol. 5, no. 5, Article ID e10659, 2010.

[18] G. Jun, J. A. Moncaster, C. Koutras et al., " $\delta$-catenin is genetically and biologically associated with cortical cataract and future alzheimer-related structural and functional brain changes," PLoS ONE, vol. 7, no. 9, Article ID e43728, 2012.

[19] E. Tamagno, P. Bardini, A. Obbili et al., "Oxidative stress increases expression and activity of BACE in NT2 neurons," Neurobiology of Disease, vol. 10, no. 3, pp. 279-288, 2002.

[20] E. Tamagno, M. Guglielmotto, M. Aragno et al., "Oxidative stress activates a positive feedback between the $\gamma$ - and $\beta$ secretase cleavages of the $\beta$-amyloid precursor protein," Journal of Neurochemistry, vol. 104, no. 3, pp. 683-695, 2008.

[21] S. Melov, N. Wolf, D. Strozyk, S. R. Doctrow, and A. I. Bush, "Mice transgenic for Alzheimer disease $\beta$-amyloid develop lens cataracts that are rescued by antioxidant treatment," Free Radical Biology \& Medicine, vol. 38, no. 2, pp. 258-261, 2005.
[22] Y. Tong, W. Zhou, V. Fung et al., "Oxidative stress potentiates BACE1 gene expression and A $\beta$ generation," Journal of Neural Transmission, vol. 112, no. 3, pp. 455-469, 2005.

[23] C. Shen, Y. Chen, H. Liu et al., "Hydrogen peroxide promotes $\mathrm{A} \beta$ production through JNK-dependent activation of $\gamma$ secretase," Journal of Biological Chemistry, vol. 283, no. 25, pp. 17721-17730, 2008.

[24] A. Oda, A. Tamaoka, and W. Araki, "Oxidative stress upregulates presenilin 1 in lipid rafts in neuronal cells," Journal of Neuroscience Research, vol. 88, no. 5, pp. 1137-1145, 2010.

[25] C. A. Rice-Evans, N. J. Miller, and G. Paganga, "Structureantioxidant activity relationships of flavonoids and phenolic acids," Free Radical Biology and Medicine, vol. 20, no. 7, pp. 933956, 1996.

[26] P. A. Kroon and G. Williamson, "Hydroxycinnamates in plants and food: current and future perspectives," Journal of the Science of Food and Agriculture, vol. 79, no. 3, pp. 355-361, 1999.

[27] A.-S. Pannala, R. Razaq, B. Halliwell, S. Singh, and C. A. RiceEvans, "Inhibition of peroxynitrite dependent tyrosine nitration by hydroxycinnamates: nitration or electron donation?" Free Radical Biology and Medicine, vol. 24, no. 4, pp. 594-606, 1998.

[28] J. Kanski, M. Aksenova, A. Stoyanova, and D. A. Butterfield, "Ferulic acid antioxidant protection against hydroxyl and peroxyl radical oxidation in synaptosomal and neuronal cell culture systems in vitro: structure-activity studies," Journal of Nutritional Biochemistry, vol. 13, no. 5, pp. 273-281, 2002.

[29] R. Sultana, A. Ravagna, H. Mohmmad-Abdul, V. Calabrese, and D. A. Butterfield, "Ferulic acid ethyl ester protects neurons against amyloid $\beta$-peptide(1-42)-induced oxidative stress and neurotoxicity: relationship to antioxidant activity," Journal of Neurochemistry, vol. 92, no. 4, pp. 749-758, 2005.

[30] J.-J. Yan, J.-Y. Cho, H.-S. Kim et al., "Protection against $\beta$ amyloid peptide toxicity in vivo with long-term administration of ferulic acid," British Journal of Pharmacology, vol. 133, no. 1, pp. 89-96, 2001.

[31] H.-S. Kim, J.-Y. Cho, D.-H. Kim et al., "Inhibitory effects of long-term administration of ferulic acid on microglial activation induced by intracerebroventricular injection of $\beta$-amyloid peptide (1 - 42) in mice," Biological and Pharmaceutical Bulletin, vol. 27, no. 1, pp. 120-121, 2004.

[32] E. H. Jung, S. R. Kim, I. K. Hwang, and T. Y. Ha, "Hypoglycemic effects of a phenolic acid fraction of rice bran and ferulic acid in C57BL/KsJ-db/db mice," Journal of Agricultural and Food Chemistry, vol. 55, no. 24, pp. 9800-9804, 2007.

[33] E. A. Hudson, P. A. Dinh, T. Kokubun, M. S. J. Simmonds, and A. Gescher, "Characterization of potentially chemopreventive phenols in extracts of brown rice that inhibit the growth of human breast and colon cancer cells," Cancer Epidemiology Biomarkers \& Prevention, vol. 9, no. 11, pp. 1163-1170, 2000.

[34] C. L. Masters, G. Simms, N. A. Weinman, G. Multhaup, B. L. McDonald, and K. Beyreuther, "Amyloid plaque core protein in Alzheimer disease and Down syndrome," Proceedings of the National Academy of Sciences of the United States of America, vol. 82, no. 12, pp. 4245-4249, 1985.

[35] A. Sgarbossa, D. Giacomazza, and M. di Carlo, "Ferulic acid: a hope for Alzheimer's disease therapy from plants," Nutrients, vol. 7, no. 7, pp. 5764-5782, 2015.

[36] K. Ono, M. Hirohata, and M. Yamada, "Ferulic acid destabilizes preformed $\beta$-amyloid fibrils in vitro," Biochemical and Biophysical Research Communications, vol. 336, no. 2, pp. 444-449, 2005. 
[37] N. Nagai and Y. Ito, "Dysfunction in cytochrome c oxidase caused by excessive nitric oxide in human lens epithelial cells stimulated with interferon- $\gamma$ and lipopolysaccharide," Current Eye Research, vol. 37, no. 10, pp. 889-897, 2012.

[38] N. Nagai, Y. Ito, and H. Sasaki, "Hyperglycemia enhances the production of amyloid $\beta_{1-42}$ in the lenses of Otsuka longevans Tokushima Fatty rats, a model of human type 2 diabetes," Investigative Ophthalmology and Visual Science, vol. 57, no. 3, pp. 1408-1417, 2016. 


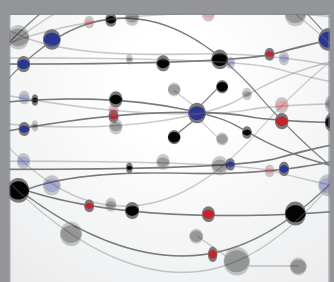

The Scientific World Journal
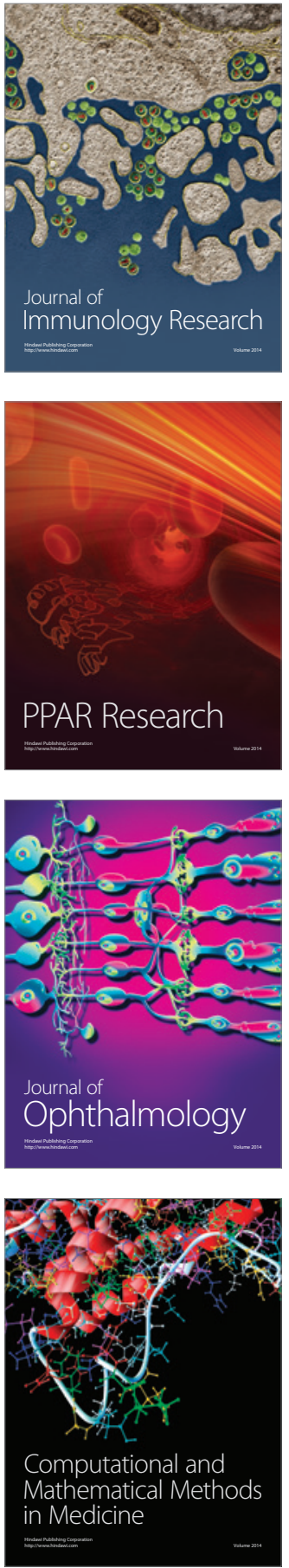

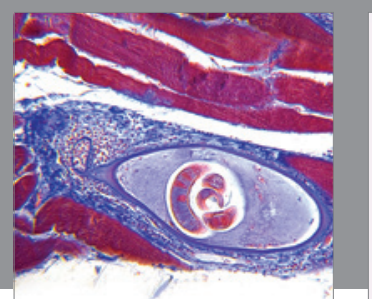

Gastroenterology Research and Practice
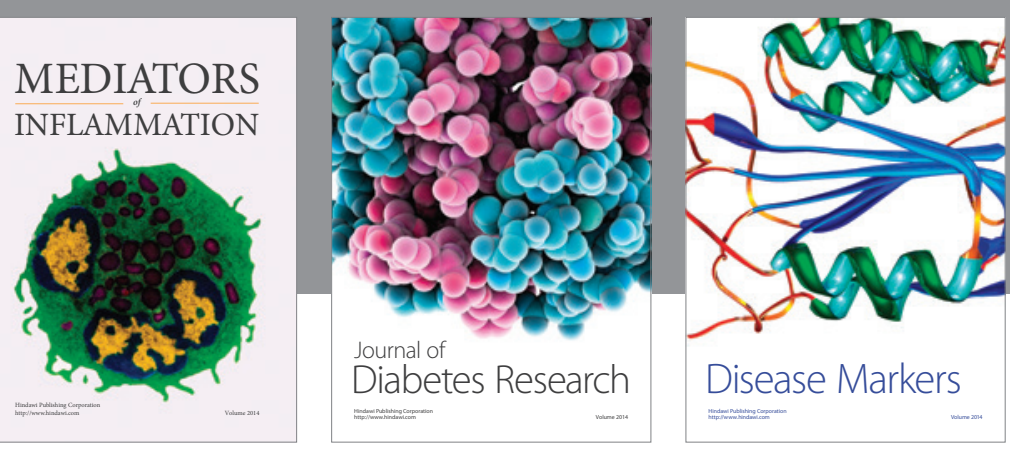

Disease Markers

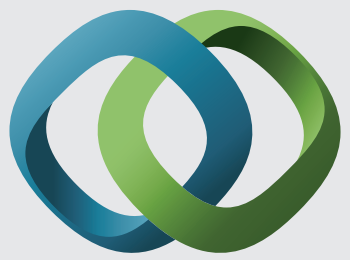

\section{Hindawi}

Submit your manuscripts at

https://www.hindawi.com
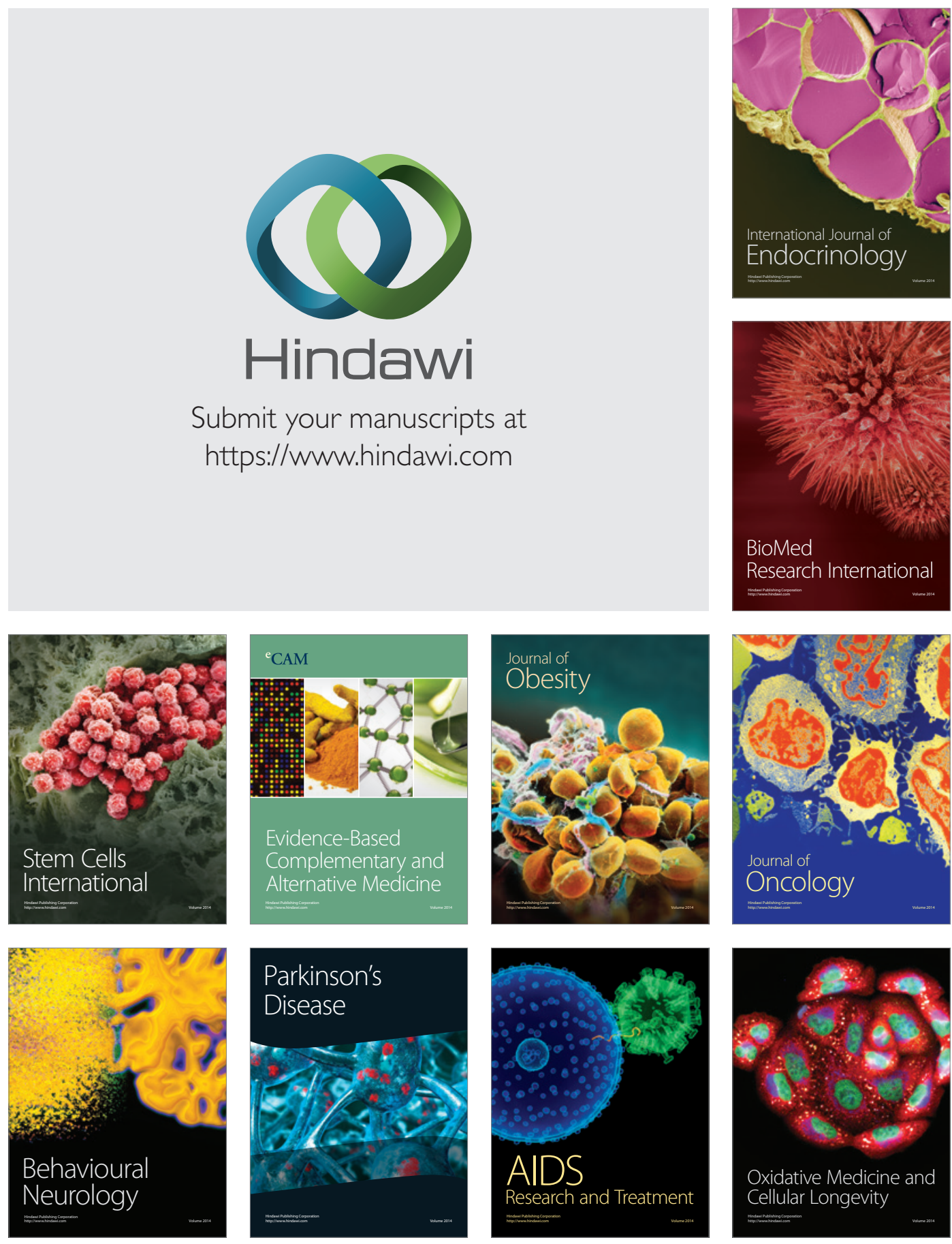